\title{
The mango tree in central and northern Benin: damage caused by fruit flies (Diptera Tephritidae) and computation of economic injury level
}

Jean-François VAYSSIÈRES ${ }^{1 *}$, Sam KORIE ${ }^{2}$, Ousmane CoulibaLY ${ }^{2}$, Cathelijne VAN MELLE ${ }^{2}$, Ludovic TeMPLE ${ }^{3}$, Djalal ARINLOYE ${ }^{2}$

${ }^{1}$ CIRAD, Persyst, UPR Hortsys, IITA, 08 BP 0932, Cotonou, Bénin j.vayssieres@cgiar.org

2 IITA, 08 BP 09 32, Cotonou, Benin

${ }^{3}$ CIRAD-ES, UMR Moïsa, TA C- $99 / 15$,

34398 Montpellier Cedex 5, France

${ }^{*}$ Correspondence and reprints

Received 11 March 2008 Accepted 10 April 2009

Fruits, 2009, vol. 64, p. 207-220 (C) 2009 Cirad/EDP Sciences All rights reserved DOI: $10.1051 /$ fruits/2009016 www.fruits-journal.org

RESUMEN EsPAÑoL, p. 220
The mango tree in central and northern Benin: damage caused by fruit flies (Diptera Tephritidae) and computation of economic injury level.

Abstract - Introduction. In the southern Sudanian zone of Benin, fruit flies are major pests and responsible for considerable yield losses in mango production. The two main species of economic importance affecting mango trees in Benin are Ceratitis cosyra and Bactrocera invadens. During the 2006 crop year and across seven main cultivars, losses stood at $17 \%$ in early April and exceeded $70 \%$ in mid-June. By the middle of the crop year, over $50 \%$ of losses occurred in mango orchards. Materials and methods. The Stone and Pedigo method was used to compute the economic injury level, using variables such as pest control costs, level of losses and mango prices. Results and discussion. The Economic Injury Level (EIL) was highly variable. For the cultivar Kent, for example, it varies from (30 to 75) fruit flies captured per ha and per week, whereas for Keitt the level ranges from (24 to 57) fruit flies ha $^{-1} \cdot$ week $^{-1}$. EIL variability depends among other things on market price fluctuation. This method is based on the early introduction of detection traps in mango orchards. A weekly monitoring of trapped fruit flies is used to compute the EIL and make a decision about pest control. Pest control (GF-120 in this case) is recommended if the gross returns exceed production costs. If the number of trapped fruit flies is below the EIL, a treatment is not recommended because pest control will not be profitable. Conclusion. The EIL is an accurate tool to set the optimal (economic) timing of pest control treatment in mango orchards. These preliminary results should lead to the introduction of integrated pest management (IPM) activities to deal with the fruit fly species that are threatening the profitability of mango production in central and northern Benin.

Benin / Mangifera indica / integrated pest management / Bactrocera invadens / Ceratitis cosyra / damage / crop losses / market prices / economic thresholds

Le manguier dans le centre et le nord du Bénin : pertes dues aux mouches des fruits (Diptera Tephritidae) et calcul du seuil économique de nuisibilité.

Résumé - Introduction. Dans la zone soudanienne méridionale du Bénin les mouches des fruits constituent la contrainte phytosanitaire majeure pour le manguier et sont responsables de pertes de production considérables. Les deux principales espèces de mouches des fruits d'intérêt économique sont Ceratitis cosyra et Bactrocera invadens. Durant la campagne 2006, les pertes moyennes enregistrées au niveau de sept cultivars étaient de $17 \%$ en début avril et dépassèrent $70 \%$ à partir de mi juin. Le seuil de $50 \%$ de pertes a été enregistré et dépassé en milieu de la campagne. Matériel et méthodes. La formule de Stone et Pedigo a été utilisée pour calculer le seuil économique de nuisibilité en utilisant des variables clés telles les coûts des traitements phytosanitaires, les pertes de rendement et les différents prix du marché pour les mangues. Résultats et discussion. Le seuil économique de nuisibilité a été très variable. Pour le cultivar Kent par exemple, ce seuil a fluctué entre (30 et 75) mouches des fruits par hectare et par semaine, alors qu'il a varié de (24 à 57) mouches pour le cultivar Keitt. Un facteur important affectant le seuil économique de nuisibilité est la fluctuation des prix du marché. La méthode est basée sur la mise en place précoce d'un piégeage de détection des mouches dans les vergers de manguiers. La collecte et le dénombrement hebdomadaire des mouches capturées dans les pièges permettront de savoir si le seuil économique de nuisibilité a été dépassé ou non. Dans l'affirmative, des méthodes de lutte déjà validées (les traitements par taches avec le GF-120 dans le cas présent) devront être mises en œuvre avec une résultante économique globalement positive. Si le nombre de mouches capturées par hectare et par semaine est inférieur au seuil, les traitements ne sont pas recommandés car la lutte n'est alors pas rentable. Conclusion. Ces résultats préliminaires devraient faciliter la mise en œuvre d'un programme de lutte intégrée contre les espèces de mouches des fruits d'intérêt économique du manguier au Bénin.

Bénin / Mangifera indica / gestion intégrée des ravageurs / Tephritidae / Bactrocera invadens / Ceratitis cosyra / dégât / perte de récolte / prix du marché / seuil économique 


\section{Introduction}

Mangos (Mangifera indica L.) are an important potential tropical commodity export and, hence, income for national and regional economies in Sub-Saharan Africa. However, a major constraint is fruit fly (Diptera, Tephritidae) damage, which is a source of economic losses in both East Africa [1] and West Africa [2, 3]. In Benin, over 70\% of the total production was lost due to fruit flies in 2005, 2006 [4] and 2007 (Vayssières et al., unpublished data). Since fruit flies are classified as quarantine insects, mango production can be banned from export if phytosanitary norms and standards are not met; this results in a loss of potential incomes along the whole value chain.

In Central and Northern Benin (Borgou department), the most important region of mango production in the country, a dozen different species of mango-infesting tephritidae have been identified. The species which cause significant economic damage are Bactrocera invadens Drew Tsuruta \& White and Ceratitis cosyra (Walker), which are the two most damaging fruit flies, followed by C.quinaria (Bezzi) and C. silvestrii Bezzi [5]. A recent survey that we conducted in the Borgou department [6] identified (i) twenty-nine mango cultivars, (ii) three main mango production systems, (iii) yield predictions for the seven main cultivars, (iv) the main market prices of these seven cultivars, (v) estimates of yield losses due to fruit flies, and (vi) estimates of equivalent income losses resulting from damage.

Given the economic importance of these pests, many research programmes have focused on pest control strategies to be used in orchards. The use of chemical treatments is not satisfactory at all since they are inefficient and economically unrewarding, they kill natural enemies of tephritid, and they have harmful effects on human health and the environment. In this context, Integrated Pest Management (IPM) appears to be particularly suitable as a cost-effective technique of fruit fly control. According to the FAO and the IOBC (International Organisation of Biological Control), Integrated Pest Management is defined as an "approach to crop protection using methods that comply with ecological, economic, and toxicological norms, giving preference to the choice of natural limitation agents, and remaining within tolerance thresholds".

A fundamental aspect of this method is that it is based on biological and economic indicators affecting pests and, therefore, their management. The following indicators can be used: the Economic Threshold (ET) and the Economic Injury Level (EIL). According to Stern [7], the Economic Threshold is "the density at which control measures should be determined to prevent an increasing pest population from reaching the economic injury level". According to Pedigo et al. [8], the Economic Injury Level is defined as "the lowest population density that will cause economic damage".

Much research has been carried out on economic injury levels for pests, such as for Plathypena scabra (F.) for soya [9], Empoasca fabae (Harris) for the potato [10], Contarinia texana (Felt) for guar [11], and Ceratitis spp. for citrus fruits [12]. The levels obviously vary from one pest to another, but the computation method is based on the same principle. Different variables must all be considered in defining an EIL for a specific pest species, in a specific agro-ecological area, and for a specific socio-economic system. Key elements for estimating an EIL for a specific crop pest, plant pest-control costs, crop-product prices, injury level (percentages) due to the pest and yield losses must all be taken into consideration.

For several decades, the Economic Injury Level has been estimated and used as a fundamental principle in assessing integrated pest management [7, 8, 13, 14]. Concerning Tephritidae, a study on Ceratitis capitata and $C$. rosa was carried out by Vincenot and Quilici for citrus fruits in Reunion Island [12]. However, there are no comparable studies for mango which refer to it.

The Economic Injury Level has not yet been assessed for pest control of tephritidae infesting mango fruit in Benin. This type of indicator was not available. Research initiated by the International Institute of Tropical Agriculture (IITA, Benin) and the Centre for International Cooperation in Agricultural Research for Development (CIRAD) over 2005 and 2006 
provided diagnostics and assessment tools of yield loss caused by tephritidae [6]. The Economic Injury Levels for these mango tephritidae can be computed by identification and measurement of the relevant biological and economic factors.

\section{Materials and methods}

Since February 2005, our research has focused on mango production in Central and Northern Benin, which is situated in the Southern Sudanian zone (lato sensu) characterised by unimodal rainfall (1000 $1100 \mathrm{~mm}$ yearly). The rainy season usually begins at the end of April and lasts until the end of October or the beginning of November, i.e., approximately 6 months.

\subsection{Experimental orchards and detection traps}

Samplings for experiments carried out on Tephritidae in the mango orchards in the Borgou department (Benin) were held in January 2005, based on the following criteria concerning the orchards considered: (i) orchard size of at least 5 ha of grafted mango trees under production, (ii) orchards with at least five marketable cultivars, (iii) orchards with regular spacing between mango trees, (iv) access to advice and guarantee of no use of chemical pesticides in the orchards, and (v) absence of other crops requiring insecticide treatment (e.g., cotton) in the vicinity of the orchards studied. In addition, a sample of five mango orchards ${ }^{1}$ included in this study was selected because they had the same planting time and, more importantly, they presented the same mix of cultivars.

In the orchards selected, and others not discussed here, we have been using Tephri-

\footnotetext{
${ }^{1}$ The five private orchards studied were located at $\left(9^{\circ} 09^{\prime} 45^{\prime \prime} \mathrm{N} ; 2^{\circ} 56^{\prime} 18^{\prime \prime} \mathrm{E}\right.$ (Tchatchou orchard); 9० 37' 01" N; $2^{\circ} 67^{\prime} 10^{\prime \prime}$ E (Korobourou 1 orchard); $9^{\circ} 38^{\prime} 75^{\prime \prime} \mathrm{N} ; 2^{\circ}$ 71' 33" E (Korobourou 2 orchard); 9० 43' 59" $\mathrm{N} ; 2^{\circ} 62^{\prime} 38^{\prime \prime} \mathrm{E}$ (Etoile Monastery in Komi) and $9^{\circ} 65^{\prime} 51^{\prime \prime} \mathrm{N} ; 2^{\circ} 67^{\prime}$ 40" E (Kakara orchard).
}

Traps (from Sorygar SL, Spain) since the beginning of 2005. Detection trapping uses parapheromones (from IPS Ltd., UK): terpinyl acetate and methyl eugenol. Terpinyl acetate traps mainly capture males of $C$ cosyra, while methyl eugenol traps mainly capture males of $B$. invadens. In each orchard, a sample of four terpinyl acetate traps and four methyl eugenol traps was set up.

The capacity of the TephriTrap is $450 \mathrm{~mL}$, with physical dimensions including (i) total height of $142 \mathrm{~mm}$, (ii) yellow base diameter of $110 \mathrm{~mm}$, (iii) height of top of $40 \mathrm{~mm}$, (iv) hole diameter of $22 \mathrm{~mm}$, and (v) invaginated hole diameter of $26 \mathrm{~mm}$. The attractant is placed in a basket in the upper part of the trap and the dimethyl-dichloro-vinylphosphate (DDVP) insecticide in the lower part. Our traps were working all year round in the field. The traps should be set up in the mango orchards at the latest at the beginning of January and can be removed in July at the end of the mango season.

In addition, we sought to find out if there were any positive correlations between the number of flies captured per trap per week and the percentage of injury recorded during the same period for the main cultivars mentioned above. Univariate and multivariate correlation analyses were carried out on $\log 10(x+1)$-transformed data using SAS [15]. Computations were made for the five orchards and the seven cultivars listed below.

\subsection{Data collection methods}

A sample of five orchards with seven grafted cultivars (mono-embryonic mango trees) each was chosen. Cultivars included: Gouverneur, Eldon, Dabshar, Kent, Smith, Keitt and Brooks, which are the most frequent cultivars (they give over $95 \%$ of total production) of our sample. Potential ripening periods in the Borgou district have already been reported [6]. Yields and yield losses were computed by sampling fruits from each of the seven cultivars in each of the sample orchards.

Yield assessments were made for two continuous cropping years (May 2005 and May 2006) [6] and losses attributed to 
Tephritidae were assessed from April to June 2006 [6]. Visible evidence of a fly oviposition puncture on a mango means that the fruit will rot. Observations were made for batches of 10 fruits. Each pierced fruit corresponds to a yield loss estimated at 10\% since we sampled 10 fruits at a time. This "pierced=rotten" connection presumes that every puncture leads to the physical loss of the fruit, which holds for production destined for regional and international export. As stipulated in the equation proposed by Pedigo et al. [8], the required data for computation of the Economic Injury Level (EIL) include production costs, seasonal prices per $\mathrm{kg}$ of mangos (minimum, average and maximum prices) and average losses due to Tephritidae per ha. This EIL is expressed in number of insects per production area unit, i.e. number of fruit flies per ha and per week.

Thus: $\mathrm{EIL}=[\mathrm{C} /(\mathrm{V} \times \mathrm{I} \times \mathrm{D} \times \mathrm{K})]$, where $\mathrm{C}$ is the cost of pest control and related activities per production unit $\left(\mathrm{FCFA} \cdot \mathrm{ha}^{-1}\right) ; \mathrm{V}$ is the market value per production unit $\left(\right.$ FCFA $\left.\cdot \mathrm{kg}^{-1}\right)$; I is the injury unit per insect per production unit; $\mathrm{D}$ is the damage per injury unit and $\mathrm{K}$ is the effectiveness of the control measure.

Other computation methods have been used, for instance, on vegetable crop pests [16], but the principle remains the same. The first section describes the different types of punctures made by fruit flies and related correlations between the fly population levels and the damage they cause to the various cultivars. Secondly, we will fill in the different variables of the equation above, using our own data provided by our first results [6]. Finally, we will show how the EIL for Tephritidae is sensitive to fluctuations in market prices.

\section{Results and discussion}

\subsection{Fruit fly population levels and damage}

\subsubsection{Symptoms and nature of damage caused by Tephritidae}

Using their ovipositor, tephritidae pierce the mangos for two reasons: oviposition, which is much more detrimental to fruit production, and, sometimes, feeding. Ceratitis sometimes lays eggs in young fruits, five or six weeks after fruit setting, as observed in Guinea [17] and demonstrated in Benin for both C. cosyra and B. invadens [6]. This means that the fruit flies are present very early in the mango orchards, well before ripening. This implies that regular monitoring of the fluctuations in the fly populations can be beneficial.

Nevertheless, egg-laying for both the Ceratitis and Bactrocera tephritidae occurs mostly when the mangos are at the pre-ripening and ripening stages. Egg-laying is sometimes difficult to detect "on the day" although a drop of sap can be visible, or, at the most, a small trickle of translucent sap emanating from the puncture [6]. On the other hand, several days after the egg-laying took place, black marks appear and infestation can be easily detected for both species [6]. An apparently innocuous puncture can hide significant internal damage with larvae tunnels and visible dejections (figure 1). Various pathogens can then speed up the biochemical processes that cause the fruit to rot.

\subsubsection{Fruit fly population dynamics}

First of all, we were able to confirm after four crop years (from 2005 to 2008) that the TephriTraps were the most efficient traps out of about ten different devices tested, either imported, purchased on local markets, or created ourselves (Vayssières et al., unpublished data). Of course, we have to use the most relevant tool for monitoring fruit fly population dynamics.

In central and northern Benin, the first species to appear in the mango orchards is Ceratitis, and, among the three main species of Ceratitis, the C. cosyra species is the most common. The first C. cosyra appear at the end of December and beginning of January when the trees start flowering, and by February they are already present in large numbers (figure 2).

We have observed that the first generations of C. cosyra can develop on two hosts: in young mangos that have fallen on the ground and in cashew apples (Anacardium occidentale). In the first case, the fly 
populations are endogenous and, in the second case, they are exogenous. Thus, when cashew nut orchards are close to mango orchards, re-infestation is very quick since the cashew nut tree bears fruit from the end of January until March. For 3 months, between March and May, the male populations of C. cosyra in mango orchards are relatively large (figure 2), with variations depending on types of orchard and their immediate environments. The C. cosyra species is abundant during the dry season but it can also be found in the rainy season.

In central and northern Benin, residual populations of the $B$. invadens species exist during the dry season but the beginning of the rainy season triggers the multiplication of their population (figure 3). The combination of certain abiotic factors (high relative humidity, rains, etc.) plus certain biotic factors (mango ripening) produces a population explosion of this highly prolific species (Vayssières et al. [4]). Male populations of B. invadens are high for the first 3 months of the rainy season from May to July (figure 3), as observed in all the orchards that we have monitored in Benin since the beginning of 2005. They peak in June, then they decrease gradually from mid-July at the latest, after the last harvests of late cultivars (Keitt, Brooks, etc.). We will demonstrate that a correlation exists between the successive ripening periods for the different cultivars and the increasing curve of the populations of this new invasive species, both in orchards growing only mangos and in orchards growing mangos and citrus fruits.

\subsubsection{Correlations between fly population levels and mango damage}

Significant damage occurs from May onwards (figure 4) and, by mid-May, i.e., mid-crop year, over 50\% losses are recorded. With the likely arrival in Benin in 2003 of the new B. invadens species of Asian origin, the extent of damage caused to mango production increased further.

The correlation ( $r$ ) between loss percentage and $B$. invadens was found to be very high for all cultivars (Gouverneur, Eldon, Dabshar, Kent, Smith, Keitt and Brooks) and

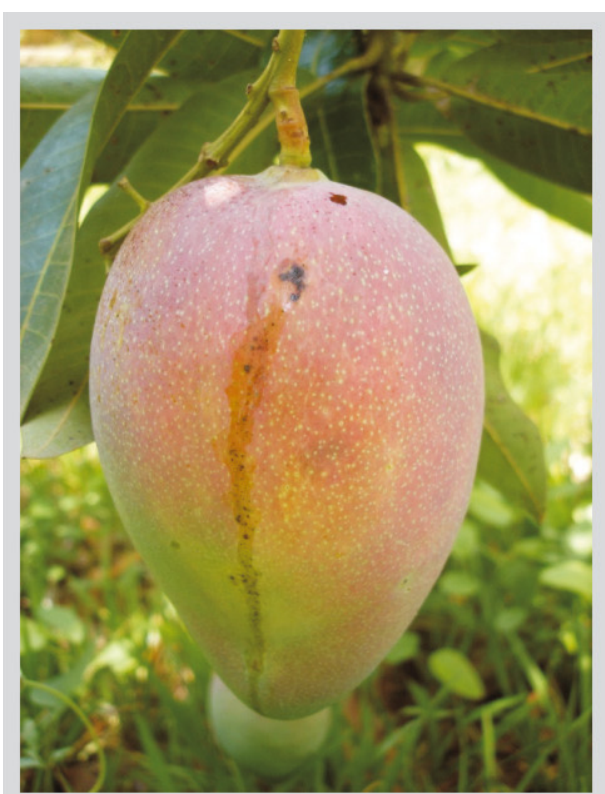

Figure 1.

External and internal damage to the same fruit of Smith cv. (Mangifera indica).

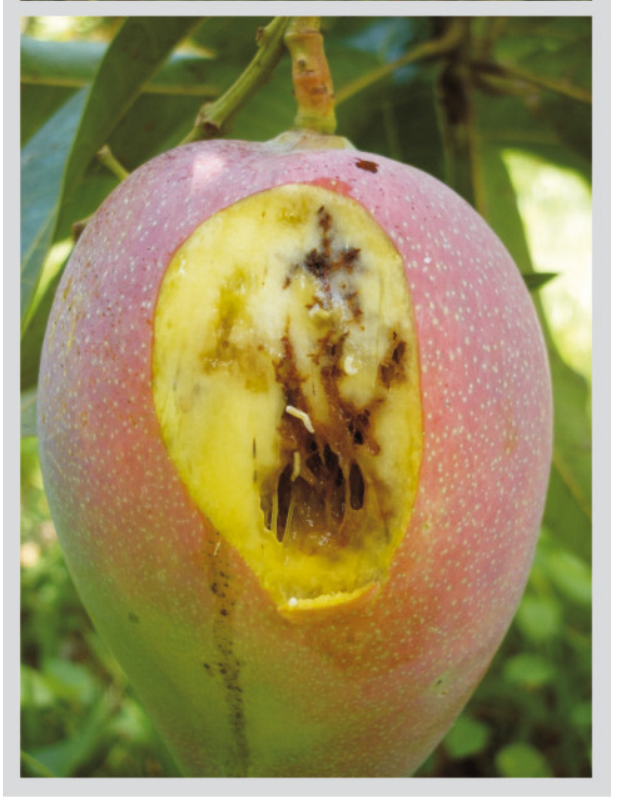

all orchards (Korobourou 1, Korobourou 2, Kakara, Tchatchou and Komiguea) (table I). The correlations between loss percentage and $B$. invadens were all positive and highly significant, while those between loss percentage and $C$. cosyra were all negative. The negative correlation between loss percentage and $C$. cosyra did not seem to be causal, which can be explained by the interaction between the two $B$. invadens and $C$. cosyra insects. When the $B$. invadens counts were 


\section{Figure 2.}

Weekly population fluctuations in male Ceratitis cosyra (Komiguea orchard, Benin) during the 2005-2006 mango seasons (Vayssières et al. [4]).

\section{Figure 3.}

Weekly population fluctuations in male Bactrocera invadens (Komiguea orchard, Benin) during the 2005-2006 mango seasons (Vayssières et al. [4]).
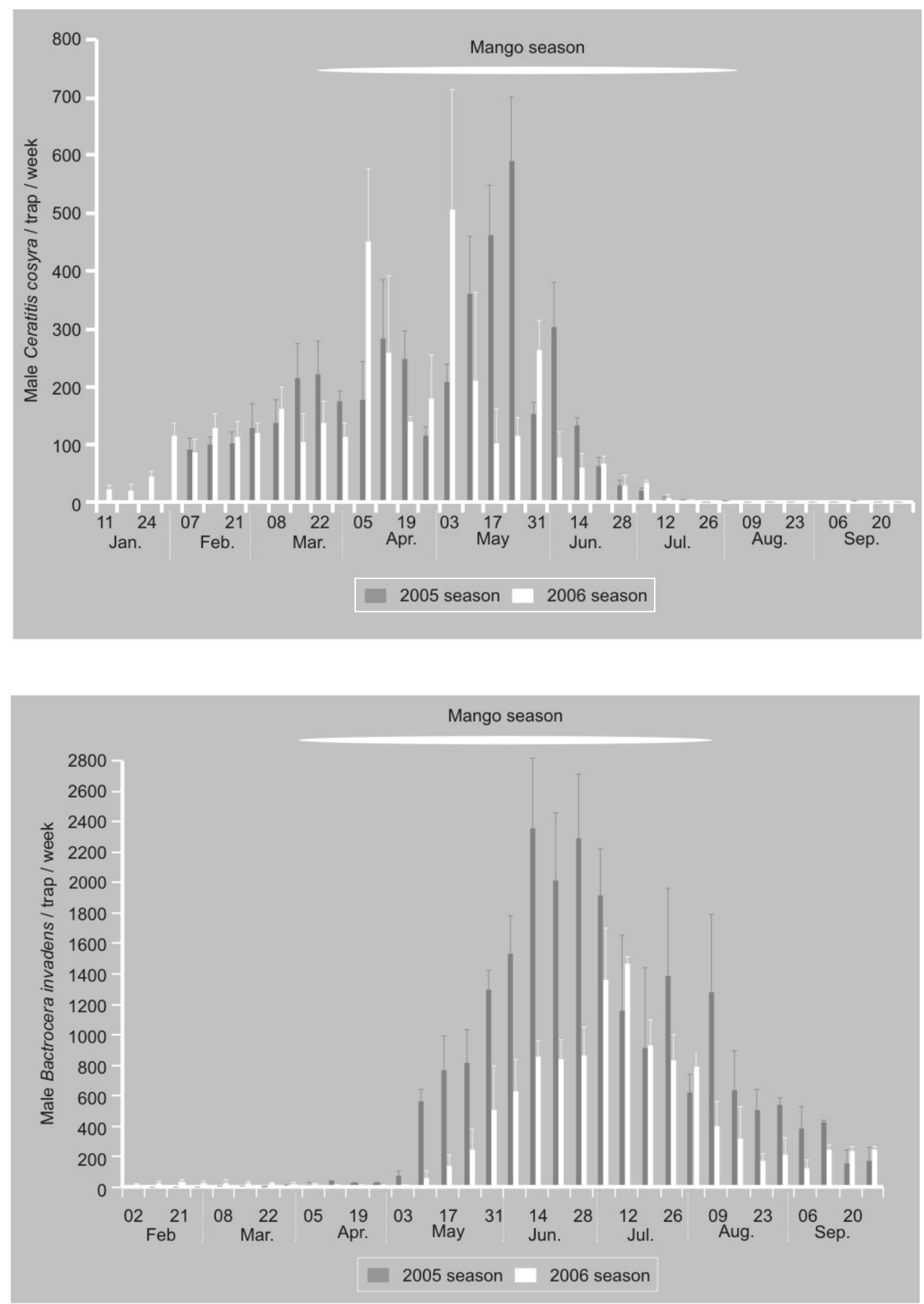

high, and, consequently, loss percentage was high, the $C$. cosyra counts were generally low. Also, when the $B$. invadens counts were low, and, consequently, loss percentage was low, the $C$. cosyra counts were generally high (table I).
A multivariate canonical correlation analysis of loss percentage with $B$. invadens and $C$. cosyra counted together gave a canonical correlation of $0.70(n=262, p<0.001)$, with B. invadens accounting for $86.7 \%$ of the total. 
The regression of loss percentage against insect abundance per unit area was therefore carried out using B. invadens counts alone since $86 \%$ of the damage was shown here to be attributed to $B$. invadens (using the canonical correlation result). Thus, the regression coefficient (slope of the regression line) was 0.053 with $r^{2}=0.50$ for B. invadens, compared with a regression coefficient of 0.040 with $r^{2}=0.31$ for both B. invadens and C. cosyra together. Again, the correlation between loss percentage and $C$. cosyra counts was negative $(r=-0.26$, $p=0.054)$; whereas the correlation between loss percentage and $B$. invadens counts was positive $(r=0.74 ; p<0.001)$. Hence, the inclusion of $C$. cosyra in the insect abundance total resulted in poor regression parameter estimates. The same pattern was observed from analysis disaggregated per cultivar.

\subsection{Variables used for the EIL calculation}

\subsubsection{Variable C: cost of pest control and related activities per production unit}

The $\mathrm{C}$ variable in our formula to calculate the EIL (Economic Injury Level) represents the cost of the pest control treatment required to significantly lower the population level of these tephritid species. Presently, the only effective method consists of spraying Success Appat (GF-120) on a weekly basis. This reduces damage caused by fruit flies by roughly $80 \%$ [18]. This product is composed of (i) plant proteins, sugary substances, various trace elements, phagostimulants for fruit flies, and (ii) spinosad, a
Table I.

Correlation coefficient between fruit fly abundance and percentages of loss presented by orchards (Benin, 2006 mango season). For all sample data $(n=262), R=0.70^{\star \star}$ for Bactrocera invadens and $R=-0.19^{\star \star}$ for Ceratitis cosyra.

\begin{tabular}{|c|c|c|}
\hline Orchards studied & B. invadens & C. cosyra \\
\hline Korobourou 1 & $R=0.74(n=57)^{\star *}$ & $R=-0.25(n=57)$ * \\
\hline Korobourou 2 & $R=0.72(n=53)^{\star *}$ & $R=-0.16(n=53) \mathrm{ns}$ \\
\hline Kakara & $R=0.71(n=55)^{\star *}$ & $R=-0.31(n=55)$ * \\
\hline Tchatchou & $R=0.78(n=48)^{* *}$ & $R=-0.09(n=48) \mathrm{ns}$ \\
\hline Komiguea & $R=0.68(n=49)^{* *}$ & $R=-0.40(n=49)$ ** \\
\hline
\end{tabular}

toxic substance produced from soil bacteria fermentation. Success Appat contains $0.24 \mathrm{~g}$ of Spinosad $\cdot \mathrm{L}^{-1}$, and it is sold in the form of a concentrated suspension to be diluted in water before use.

One litre of Success Appat is needed for one treatment per hectare. In Benin, the estimated market price of the Success Appat, including transport costs, is expected to be 10000 FCFA per litre. An effective treatment requires about 12 weekly doses (table II). The costs for a manual sprayer are around 50000 FCFA (table II). Total treatment costs per ha amount to 170000 FCFA. In addition, in order to use the treatment correctly, the field has to be cleared beforehand, and then at least twice a year. Costs of field maintenance amount to $40000 \mathrm{FCFA} \cdot \mathrm{ha}^{-1} \cdot \mathrm{year}^{-1}$ based on two field clearings per year (including firebreaks) (table II). Finally, monitoring of the fruit fly populations is carried out using traps containing fruit fly attractants. These traps need to be monitored for one year, including the prices of

\section{Table II.}

Total spot treatment (BAT) management cost per ha of mango orchard treated with Success Appat (GF-120) (Borgou, Benin).

\begin{tabular}{|c|c|c|c|c|c|}
\hline Treatment & $\begin{array}{l}\text { Unit cost } \\
\text { (FCFA) }\end{array}$ & $\begin{array}{c}\text { Number of treatments } \\
\text { per week }\end{array}$ & $\begin{array}{l}\text { Number of treatments } \\
\text { per month }\end{array}$ & $\begin{array}{c}\text { Number of treatments } \\
\text { per year }\end{array}$ & $\begin{array}{l}\text { Total cost } \\
\text { (FCFA) }\end{array}$ \\
\hline Gf-120 treament & 10000 & 12 & - & - & 120000 \\
\hline Manual sprayer & - & - & - & - & 50000 \\
\hline Field clearing & 20000 & - & - & 2 & 40000 \\
\hline Detection fly trapping & - & - & 12 & - & 20000 \\
\hline
\end{tabular}


Table III.

Mango farm-gate price (FCFA) variability according to cultivars in the Borgou department (Benin, 2006 mango season) (synthetised from Vayssières et al. [6]).

\begin{tabular}{|c|c|c|c|c|c|c|c|c|c|}
\hline \multirow[t]{2}{*}{ Cultivars } & \multicolumn{2}{|c|}{ Minimum price } & \multirow[b]{2}{*}{$\begin{array}{l}\text { Mid-crop } \\
\text { year }\end{array}$} & \multicolumn{2}{|c|}{ Maximum price } & \multirow[b]{2}{*}{$\begin{array}{l}\text { Start of } \\
\text { crop year }\end{array}$} & \multirow[b]{2}{*}{$\begin{array}{c}\text { End of } \\
\text { crop year }\end{array}$} & \multicolumn{2}{|c|}{ Average price } \\
\hline & $\begin{array}{l}\text { Unit } \\
\text { price }\end{array}$ & $\begin{array}{l}\text { Price } \\
\text { per kg }\end{array}$ & & $\begin{array}{l}\text { Unit } \\
\text { price }\end{array}$ & $\begin{array}{c}\text { Price per } \\
\text { kg }\end{array}$ & & & $\begin{array}{l}\text { Unit } \\
\text { price }\end{array}$ & $\begin{array}{c}\text { Price per } \\
\text { kg }\end{array}$ \\
\hline Gouverneur & 10 & 40 & 13 April-30 April & 25 & 100 & 28 March-12 April & - & 20 & 70 \\
\hline Eldon & 10 & 30 & 18 April-15 May & 25 & 70 & 3 April-17 April & - & 20 & 50 \\
\hline Dabshar & 10 & 20 & 1 May-29 May & 20 & 40 & 17 April-30 April & - & 15 & 30 \\
\hline Kent & 10 & 20 & 1 May-29 May & 25 & 50 & 17 April-30 April & 30 May-19 June & 20 & 35 \\
\hline Smith & 10 & 20 & 10 May-5 June & 25 & 55 & - & 6 June-25 June & 20 & 38 \\
\hline Keitt & 10 & 25 & 15 May-19 June & 25 & 60 & - & 20 June-5 July & 20 & 43 \\
\hline Brooks & 10 & 20 & 29 May-25 June & 25 & 45 & - & 26 June-15 July & 20 & 33 \\
\hline
\end{tabular}

the traps and the changes of the parapheromone cylinders with DDVP pastilles once a month, costing about $20000 \mathrm{FCFA} \cdot \mathrm{ha}^{-1}$ (table II)

Total management costs (C) amount to $230000 \mathrm{FCFA} \cdot \mathrm{ha}^{-1}$, including field clearing costs (clearing, firebreaks), pest control treatment (Success Appat: GF-120), and yearly monitoring of the fly populations in the orchard (table II). Fields being owned, it is assumed that no costs (land) are entailed for land.

\subsubsection{Variable V: market value per product unit}

The farm-gate prices of the fruits for the seven different cultivars, according to the different harvesting period data, were collected in Borgou over the year 2006 (table III). When production is at its peak, i.e., in mid-crop year, the average weighted price is at its lowest because mangos are abundant and demand is met. Prices vary with cultivar and the minimum price per $\mathrm{kg}$ of mangos ranges from $20 \mathrm{FCFA} \cdot \mathrm{kg}^{-1}$ (cvs Kent, Smith, Brooks) to $40 \mathrm{FCFA} \cdot \mathrm{kg}^{-1}$ (cv. Gouverneur).

At the beginning of the crop year, the average weighted price is at its peak because supply is lower than demand. Maximum prices range from $50 \mathrm{FCFA} \cdot \mathrm{kg}^{-1}$ (Kent) to 100 FCFA $\mathrm{kg}^{-1}$ (cv. Gouverneur). At the end of the crop year, these prices range from $45 \mathrm{FCFA} \cdot \mathrm{kg}^{-1}$ (cv. Brooks) to 60 FCFA $\mathrm{kg}^{-1}$ (cv. Keitt). Using these two extremes, we can compute an average weighted price for each cultivar (table III).

\subsubsection{Variable I: injury unit per insect and per production unit}

In 2006, average levels of damage caused by tephritidae were estimated, for two monitoring periods (beginning of May and beginning of June 2006), for the seven main mango cultivars, in order of ripening during the crop year: cvs. Gouverneur, Eldon, Dabshar, Kent, Smith, Keitt and Brooks (figure 4). In the five orchards studied, the lowest average of damage was observed on the Gouverneur cultivar (19\%), and the highest average of damage on the Brooks cultivar (63\%). Average levels of damage of the other cultivars were Eldon (60\%), Dabshar (44\%), Kent (45\%), Smith (49\%) and Keitt (53\%). We can observe that the damage level increases during the season.

\subsubsection{Variable $D$ : damage per injury unit}

Mango tree yield varies between years because of both biotic factors (physiological, entomological) and abiotic factors (climatic). One unavoidable physiological factor is the well-known "alternate year" phenomenon. Apart from this physiological factor, yield losses are highly correlated with fluctuations in fruit fly populations. Disparities between yield losses for the different cultivars can be put down to several intrinsic and extrinsic factors [6]. 


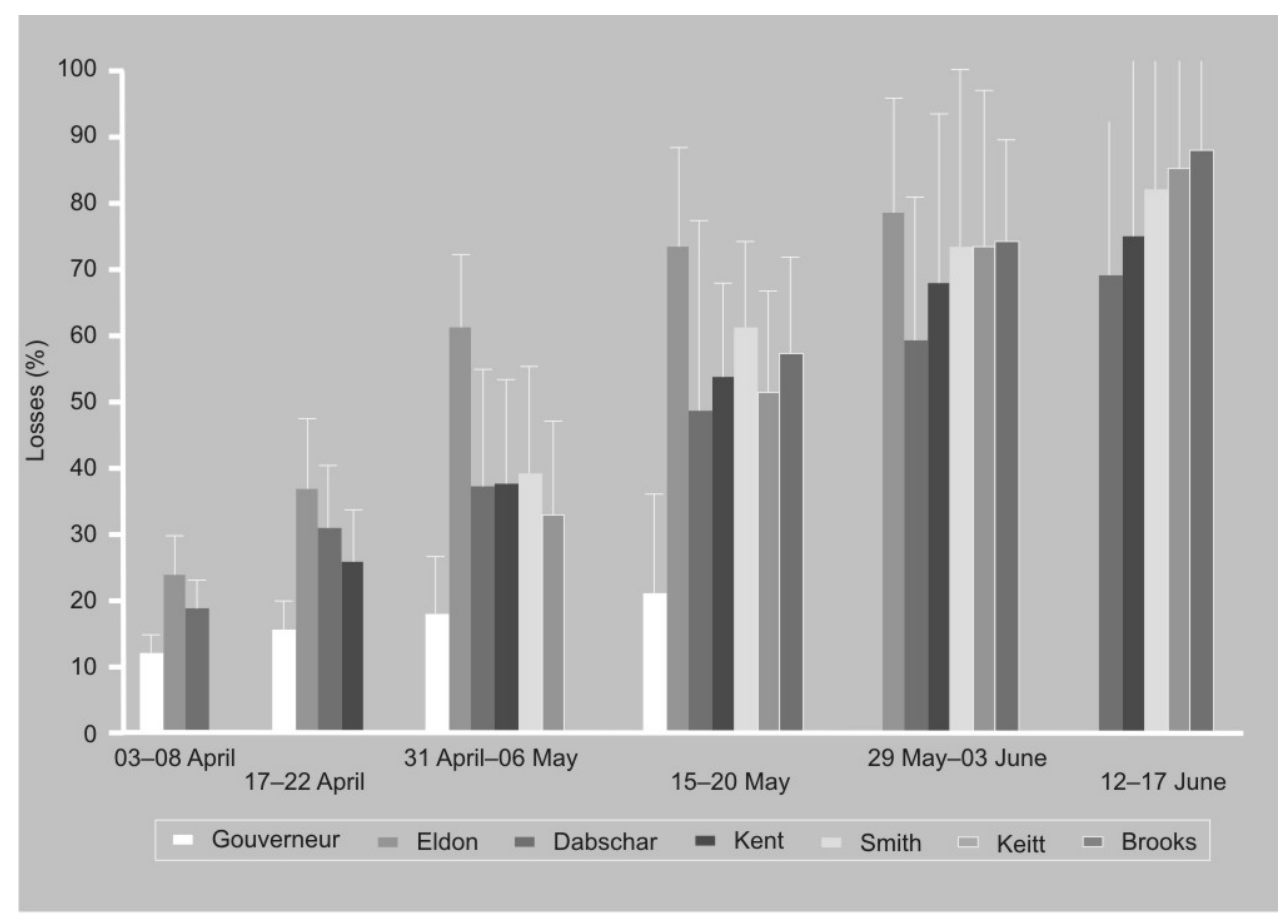

Figure 4.

Average damage caused by Tephritidae to seven different cultivars in five mango orchards in North Parakou (Benin, 2006 crop year). Source: Vayssières et al. [6].

\section{Table IV.}

Losses caused by fruit flies and average sale prices for fruits of seven main mango cultivars found in five orchards studied in the Borgou department (Benin, 2006 mango season) (Vayssières et al. [6]).

\begin{tabular}{|c|c|c|c|c|c|c|}
\hline $\begin{array}{l}\text { Mango } \\
\text { cultivar }\end{array}$ & $\begin{array}{l}\text { Average } \\
\text { yield } \\
\left(\mathrm{t} \cdot \mathrm{ha}^{-1}\right)\end{array}$ & $\begin{array}{l}\text { Average damage } \\
\text { per cultivar } \\
\text { and per tree } \\
(\%)\end{array}$ & $\begin{array}{l}\text { Yield losses } \\
\qquad\left(\mathrm{t} \cdot \mathrm{ha}^{-1}\right)\end{array}$ & $\begin{array}{l}\text { Theoretical } \\
\text { average sale price } \\
\text { without fruit flies } \\
\left(\text { FCFA } \cdot \mathrm{t}^{-1}\right)\end{array}$ & $\begin{array}{l}\text { Financial loss due to fruit flies } \\
\text { (using average price) } \\
\left.\text { (FCFA } \cdot \mathrm{t}^{-1}\right)\end{array}$ & $\begin{array}{c}\text { Financial loss of yield } \\
\text { (using average price) } \\
\text { (FCFA } \cdot \mathrm{ha}^{-1} \text { ) }\end{array}$ \\
\hline Gouverneur & 1.803 & 19 & 0.342 & 70000 & 13300 & 23940 \\
\hline Eldon & 8.864 & 60 & 5.318 & 50000 & 30000 & 265900 \\
\hline Dabshar & 2.883 & 44 & 1.268 & 30000 & 13200 & 38040 \\
\hline Kent & 5.928 & 45 & 2.667 & 35000 & 15750 & 93345 \\
\hline Smith & 9.102 & 49 & 4.459 & 38000 & 18620 & 169442 \\
\hline Keitt & 6.091 & 53 & 3.228 & 43000 & 22790 & 138804 \\
\hline Brooks & 10.407 & 63 & 6.556 & 33000 & 20790 & 216348 \\
\hline
\end{tabular}

In our samplings, losses caused by Tephritidae varied from $(0.34$ to 6.55$) \mathrm{t} \cdot \mathrm{ha}^{-1}$ with cultivar (table IV), which involved major income losses for the five mango orchards, which cover a total area of 58 ha. Yield losses per cultivar and per hectare result in high losses of potential incomes when using the average weighted price (table IV). Variability in income loss per hec- tare for the different cultivars is partly due to their respective market prices.

\subsubsection{Variable K: effectiveness of the control measure}

Spot treatment using Success Appat (GF120) considerably reduces losses caused by tephritidae, and is currently one of the most 


\section{Table V.}

The Economic Injury Level (EIL) values (in number of tephritidae $\cdot$ ha $^{-1}$. week ${ }^{-1}$ ) calculated with different prices of mangos (mango season 2006) for seven main cultivars found in Benin according to Pedigo et al. [8].

$\begin{array}{lccc}\text { Cultivar } & \text { EIL } & \text { EIL } & \text { EIL } \\ & \text { with minimum price } & \text { with } & \begin{array}{c}\text { maximum price } \\ \text { Gouverneur }\end{array} \\ \text { Eldon } & 269 & 107 & 153 \\ \text { Dabshar } & 21 & 9 & 13 \\ \text { Kent } & 156 & 78 & 104 \\ \text { Smith } & 75 & 30 & 43 \\ \text { Keitt } & 36 & 13 & 19 \\ \text { Brooks } & 57 & 24 & 33 \\ & 20 & 9 & 12\end{array}$

effective control measures available [18]. In 2006 and in 2007, larvae infestation was significantly lower in plots treated with GF-120 compared with untreated control plots. During the 2008 mango season, we obtained the same results in Borgou (Vayssières et al., unpublished data).

Since only a combined application of several IPM control methods can drastically reduce fly population, we used several together. For instance, in 2008, GF-120 was tested in combination with other methods (such as orchard sanitation) or by combining it with an approach consisting of protecting and increasing the populations of weaver ants in orchards. We recorded the overall performance of the various combinations of these methods, because the weaver ants (Oecophylla longinoda) are not attracted by the food components contained in GF-120. This confirms the compatibility of GF-120 with biological control methods (generalist predators and parasitoids as well).

\subsection{Economic injury level of mango fruit flies}

The example of the Kent cultivar was used in our study for calculating the Economic Injury Level (EIL). This cultivar has an average market value, even though variables $\mathrm{I}$ and $\mathrm{D}$ change value for each cultivar. Thus, retaining C $\left(=230000 \mathrm{FCFA} \cdot \mathrm{ha}^{-1}\right)$, $\mathrm{I}(=39 \%), \mathrm{D}\left(=4896 \mathrm{t} \cdot \mathrm{ha}^{-1}\right)$ and $\mathrm{K}(=0.8$; scale from 0 to 1 ) as constant values for the
Kent cultivar, a sensitivity analysis was used by varying market prices $[(20,35$ or 50) FCFA $\left.\cdot \mathrm{kg}^{-1}\right]$.

Taking the average price, i.e., 35 FCFA $\cdot \mathrm{kg}^{-1}$, of Kent mangos (table III), the average density level of tephritidae causing economic loss to Kent production is 43 tephritidae $\cdot \mathrm{ha}^{-1} \cdot \mathrm{week}^{-1}$ (table V). Taking the maximum price, i.e., $50 \mathrm{FCFA} \cdot \mathrm{kg}^{-1}$ (table III), the EIL stands at 30 tephritidae $\cdot$ ha $^{-1} \cdot$ week $^{-1}$ (table V). Lastly, taking the minimum price, i.e., $20 \mathrm{FCFA} \cdot \mathrm{kg}^{-1}$ (table III), the EIL reaches 75 tephritidae $\cdot \mathrm{ha}^{-1}$. week $^{-1}$ (table V).

We computed the averages of the various thresholds for the five orchards studied (table VI), differentiating the thresholds for early cultivars, seasonal cultivars and late cultivars. As the early cultivars in these orchards are predominantly Gouverneur and Eldon, the average threshold for these five orchards will be 83 tephritidae. $\mathrm{ha}^{-1} \cdot$ week $^{-1}$ in March and April (table VI). The seasonal cultivars in these orchards are predominantly Dabshar and Kent and so the average threshold will be 73 tephritidae $\mathrm{ha}^{-1}$. week $^{-1}$ in May for four out of five orchards (table VI).

How can these threshold figures be used? Before the start of the mango crop year, fly traps are set up, using one or two detection traps per ha. For our experiments, we had installed four terpinyl-acetate traps and four methyl-eugenol traps in each orchard, when covering 5-6 ha or more. The optimal date for setting up the traps depends on numerous factors including key factors such as agro-ecological zone and cultivar. Since we count the number of flies captured each week in each trap, we can know immediately if the EIL threshold has been reached or not, and if so treatment can be applied. Hence, once the threshold has been reached, pest control treatment using Success Appat (GF-120) should begin, because additional profits will exceed the treatment costs. On the other hand, beneath these thresholds, the GF-120 treatment should not be used because control does not pay off. Our computations are based on unit area, using the hectare, and the "threshold number" of fruit flies per trap depends solely on the number of traps used per ha. 


\begin{tabular}{|c|c|c|c|c|c|c|}
\hline Mango orchards & Early cultivar & $\begin{array}{l}\text { EIL per } \\
\text { early } \\
\text { cultivar }\end{array}$ & $\begin{array}{c}\text { Mean EIL to be respected in } \\
\text { March and April in Borgou per } \\
\text { orchard }\end{array}$ & $\begin{array}{l}\text { Season } \\
\text { cultivar }\end{array}$ & $\begin{array}{l}\text { EIL per season } \\
\text { cultivar }\end{array}$ & $\begin{array}{l}\text { Mean EIL to be } \\
\text { respected in May in } \\
\text { Borgou per orchard }\end{array}$ \\
\hline \multirow[t]{2}{*}{ Korobourou 1} & Eldon & 13 & 83 & Dabschar & 104 & 73 \\
\hline & Gouverneur & 153 & & Kent & 43 & \\
\hline \multirow[t]{2}{*}{ Korobourou 2} & Eldon & 13 & 83 & Dabschar & 104 & 73 \\
\hline & Gouverneur & 153 & & Kent & 43 & \\
\hline \multirow[t]{2}{*}{ Kakara } & Eldon & 13 & 83 & Kent & 43 & 75 \\
\hline & Gouverneur & 153 & & Gouverneur & 107 & \\
\hline \multirow[t]{2}{*}{ Tchatchou } & Eldon & 13 & 83 & Dabschar & 104 & 73 \\
\hline & Gouverneur & 153 & & Kent & 43 & \\
\hline \multirow[t]{2}{*}{ Komiguea } & Eldon & 13 & 83 & Dabschar & 104 & 73 \\
\hline & Gouverneur & 153 & & Kent & 43 & \\
\hline
\end{tabular}

Taking the example of the Komiguea orchard, the number of male C. cosyra increased rapidly and the EIL was reached by February (figure 3). Therefore, treatment must begin in February as soon as the trap results reach the thresholds indicated for this orchard (table VI). Also, there were significant numbers of male $B$. invadens during May, and the EIL was reached during the first half of May (figure 4), so treatment must begin in May. However, if pest control against Ceratitis has begun in February, then the female $B$. invadens populations will not be as high in the months that follow (MayJune).

This method and these results call for some additional explanations. Firstly, in these computations we cannot differentiate one fly species from the other, which means that, at the threshold level, we cannot separate the numbers of Ceratitis from the numbers of Bactrocera. Therefore, all fruit fly species having an economic impact are counted here. Also, it must be stressed that it is relatively difficult to efficiently control fruit fly populations if treatment is initiated too late and the crop year is already underway. Previous studies have shown that fruit fly numbers can increase very quickly and particularly so if no prophylactic measures are taken. Computing the EIL is thus a tool for monitoring the fly populations and defining the moment of treatment to prevent any major demographic growth of these pests.

Numerous factors can significantly affect EIL computations. Hence, even a slight change in mango market price or in the cost of GF-120 treatment can affect computations and the EIL itself. As already explained, market price is one obvious factor affecting EIL variability. Other EIL studies have been carried out on the market prices of other agricultural products, horticultural crops and cereals. For thrips (Frankliniella occidentalis) damaging strawberries and other garden crops, the EIL varies from five thrips per fruit when strawberry prices are low, to sixteen thrips per fruit when prices are high [19].

EIL is computed at the plot level. Yet, one of the variables in the equation (cost in FCFA $h^{-1}$ ) is not stable and depends on farm size. This cost can vary according to economies of scale that can be either technical (depreciation of fixed costs) or commercial (input purchase price differential) or even according to the value attributed to family labour depending on farm type. Testing the method has revealed how useful and feasible it is for mango production in the context of the small farms we studied. General use would, however, entail adjustment of the different variables in the equation to account for specific agro-ecological and 
socio-economic environments. It would also require back-up support to provide the techno-economic data for redefining the proposed indicator. The data provided in this paper was produced in an experimental research context.

It should be pointed out that this indicator has proved to be beneficial for other crops. Despite some difficulties involved in estimating it and applying it, the EIL notion has contributed considerably to the reduction of insecticide use for many crops [12, 13, 20]. The EIL approach also remains appropriate when treatment based on GF-20 is used in Africa for integrated pest control of fruit flies.

\section{Conclusion}

Given the yield losses attributed to tephritidae, these mango pests are of major economic importance in Benin. They are not only a major menace to mangos as a fruit crop, but also to the survival of the mango production sector. Certain mango orchards were unfortunately cut down in 2006 and 2007 in Borgou [21] by their owners "because of the flies". In such cases, sector competitiveness may have decreased. These are strong signals which can only alert us to the urgency of implementing efficient control techniques for dealing with mango fruit flies. Treatment using GF-120 is one of the most promising methods of integrated pest control and it is among the most innovative of the techniques currently available and ready for use. The Economic Injury Level is a proven tool, allowing pest control treatment to be applied at the right time from a micro-economic point of view.

Recording the production losses caused by tephritidae, and monitoring fly population fluctuations and their economic injury levels are useful in setting up effective and efficient control programmes against these quarantine pests. Systematic use of these indicators would, however, entail adjustment of certain variables so that the diverse structures and the different locations involved are taken into account. This type of study could be carried out in several other West African countries, so that the different results obtained from the various agro-ecological zones and the various socio-economic contexts can be compared. These indicators are useful tools for upgrading the overall mango value chain through effective and efficient pest control, leading to more income in areas where poverty is predominant.

\section{Acknowledgements}

We are extremely grateful to all the growers in the Borgou department for their warm welcome, and for the encouragement they gave to our work over the two years of studies. We especially thank M. Wallis Zoumarou for his support (Korobourou). This research was funded by Coopération Française (Cotonou, Benin), the International Institute of Tropical Agriculture (IITA, Benin) and the Centre for International Cooperation in Agricultural Research for Development (CIRAD, France); we are most thankful for the confidence they have shown in our work. We also extend our sincere thanks to Antonio Sinzogan, Henri Vannière, and to two unnamed reviewers for their helpful remarks.

\section{References}

[1] Lux S.A., Ekesi S., Dimbi S., Mohamed S., Billah M., Mango-infesting fruit flies in Africa: perspectives and limitations of biological approaches to their management, in: Neuenschwander P., Borgemeister C., Langewald J. (Eds.), Biological control in IPM systems in Africa, CAB Int., Wallingford, UK, 2003, pp. 277-298.

[2] Vayssières J.-F., Sanogo F., Noussourou M., Inventory of the fruit fly species (Diptera: Tephritidae) linked to the mango tree in Mali and tests of integrated control, Fruits 62 (2007) 329-341.

[3] Vannière H., Didier C., Rey J.-Y., Diallo T.M., Keita S., Sangaré M., The mango in Frenchspeaking West Africa: cropping systems and agronomical practices, Fruits 62 (2007) 187201. 
[4] Vayssières J.-F., Korie S., Ayégnon D., Correlation of fruit fly (Diptera Tephritidae) infestation of major mango cultivars in Borgou (Benin) with abiotic and biotic factors and assessment of damage, Crop Protection 28 (2009) 477-488.

[5] Vayssières J.-F., Georgen G., Lokossou O. Dossa P., Akponon C., A new Bactrocera species in Benin among mango fruit fly (Diptera: tephritidae) species, Fruits 60 (2005) 371-377.

[6] Vayssières J.-F., Korie S., Coulibaly T. Temple L., Boueyi S., The mango tree in northern and central Benin: cultivar inventory, yield assessment, early infested stages of mangos and economic loss due to the fruit fly (Diptera Tephritidae), Fruits 63 (2008) (6) 335-348.

[7] Stern V.M., Economic threshold, Annu. Rev. Entomol. 18 (1973) 259-280.

[8] Pedigo L.P., Hutchins S.H., Higley L.G., Economic Injury Levels in theory and practice, Annu. Rev. Entomol. 31 (1986) 341-368.

[9] Stone J.D., Pedigo L.P., Development and Economic injury level of the green cloverworm on Soybean in lowa, J. Econ. Entomol. 65 (1972) 197-201.

[10] Walgenbach J.F., Wyman J.A., Dynamic action threshold levels for the potato leafhopper (Homoptera Cicadellidae) on potatoes in Wisconsin, J. Econ. Entomol. 77 (1984) 1335-1340.

[11] Rogers C. E., Economic injury level for Contarinia texana on Guar, J. Econ. Entomol. 69 (1976) 693-696.

[12] Vincenot D., Quilici S., Lutte raisonnée en vergers d'agrumes à la Réunion : expérimentation et développement, Fruits 50 (1995) (1) 27-38.
[13] Pedigo L.P., Higley L.G., The economic injury level concept and environmental quality: a new perspective, Am. Entomol. 38 (1992) 12-21.

[14] Oerke E.C., Crop losses to pests, J. Agric. Sci. 144 (2005) 31-43.

[15] Anon., The SAS System for Windows, version 9.1, SAS Inst. Inc., Cary, NC, USA, 2003.

[16] Sanchez J.A., Canovas F., Lacasa A., Thresholds and management strategies for Aulacorthum solani (Hemiptera Aphididae) in greenhouse pepper, J. Econ. Entomol. 100 (1) (2007) 123-130.

[17] Vayssières J.-F., Rapport d'activités de 1991 à 1995 à la Filière Fruits, Cent. Rech. Agron. Foulaya, Doc. Interne, IRAG / Minist. Agric. Elev. For., Conakry, Guinée, 1995, 78 p.

[18] Vayssières J.-F., Sinzogan A., Ouagoussounon I., Korie S., Thomas Odjo A., Effectiveness of Spinosad Bait Sprays (GF-120) in controlling mango-infesting fruit flies (Diptera: Tephritidae) in Benin, J. Econ. Entomol. 102 (2009) 515-521.

[19] Coll M., Shakya S., Shouster I., Nenner Y., Steinberg S., Decision-making tools for Frankliniella occidentalis management in strawberry: consideration of target markets, Entomol. Exp. Appl. 122 (2007) 59-67.

[20] Hailé F.J., Highley L.G., Specht J.E., Soybean cultivars and insects defoliation: yield loss and economic injury levels, Agron. J. 90 (1988) 344-352.

[21] Vayssières J.-F., D'autres conséquences des importants dégâts dus aux mouches des fruits sur manguiers : la lutte régionale contre les Tephritidae en Afrique de l'Ouest, in: Lett. Inf. (Coleacp-Cirad) 3 (2007) 2. 
El mango en el centro y norte de Benín: pérdidas a causa de las moscas de las frutas (Diptera Tephritidae) y cálculo del umbral económico de nocividad.

Resumen - Introducción. En la zona sudanesa meridional del Benín las moscas de las frutas constituyen el mayor problema fitosanitario para el mango y son además responsables de las considerables pérdidas de producción. Las dos especies principales de mosca de las frutas en cuanto al interés económico son Ceratitis cosyra y Bactrocera invadens. Durante la campaña de 2006, las medias de las pérdidas registradas a nivel de siete cultivares, eran del $17 \%$ a principios de abril y sobrepasaban el $70 \%$ a partir de mediados de junio. El umbral del $50 \%$ de pérdidas se registró y se sobrepasó a mitad de campaña. Material y métodos. Se empleó la fórmula de Stone y Pedigo para calcular el umbral económico de nocividad mediante el uso de variables clave, tales como los costes de los tratamientos fitosanitarios, las pérdidas de rendimiento, así como los diferentes precios del mercado de los mangos. Resultados y discusión. El umbral económico de nocividad fue muy variado. Para el cultivar Kent, por ejemplo, este umbral fluctuó entre (30 y 75) moscas de las frutas por hectárea y por semana, mientras que varió de (24 a 57) moscas para el cultivar de Keitt. Un factor importante, que afectó el umbral económico de nocividad, es la fluctuación de los precios del mercado. El método está basado en la instalación precoz de una trampa de detección de las moscas en los vergeles de mangos. La colecta y recuento semanal de las moscas capturadas en las trampas permitirá averiguar si se superó o no el umbral económico de nocividad. En caso afirmativo se tendrán que instaurar métodos de control ya validados (los tratamientos por manchas gracias al GF-120 en el presente caso) con un resultado económico globalmente positivo. Si el número de moscas capturadas por hectárea y por semana es inferior al umbral, no se recomiendan los tratamientos, ya que entonces el control no resulta rentable. Conclusión. Estos resultados preliminares deberían facilitar la instauración de un programa de control integrado contra las especies de moscas de las frutas en cuanto al interés económico del mango en Benín.

Benin / Mangifera indica / Gestión de lucha integrada / Bactrocera invadens / Ceratitis cosyra / daños / pérdidas de la cosecha / precios de mercado / umbral económico 